Muhammad Hamdani: Penerapan Metode Membaca Alquranpada Tpa Di Kecamatan Amuntai Utara (Studi Pada Metode Iqra Dan Metode Tilawati)

\title{
PENERAPAN METODE MEMBACA ALQURAN PADA TPA DI KECAMATAN AMUNTAI UTARA (Studi pada metode Iqra dan metode Tilawati)
}

\author{
Oleh : Muhamad Hamdani
}

\begin{abstract}
Abstrak
Penelitian ini bertujuan mengetahui bagaimana penerapan metode membaca Alquran pada TPA dikecamatan Amuntai Utara dengan permasalahan yang akan diangkat yaitu bagaimana Struktur pembelajaran ( Kurikulum), pendekatan yang dilakukan, langkah-langkah pembelajaran serta seperti apa karakteristik para Ustadz dan Ustdzah pengajar dan seberapa besar efektifitas metode yang diterapkan. Pendekatan penelitian ini menggunakan pendekatan mixed Method yakni metode yang memadukan pendekatan kualitatif dan kuantitatif dalam hal metodologi (seperti dalam tahap pengumpulan data), dan kajian model campuran memadukan dua pendekatan dalam semua tahapan proses penelitian. Pengumpulan data dilakukan dengan teknik observasi, wawancara, tes dan dokumenter. Adapun analisis data yang digunakan adalah analisis diskriptif kualitatif untuk menjawab bagaimana penerepan metode membaca Alquran pada TPA di Kecamatan Amuntai Utara, sedangkan untuk mengukur Seberapa besar efektifitas metode membaca Alquran pada TPA di kecamatan Amuntai Utara digunakan analisis kuantitatif dengan menggunakan software SPSS untuk melihat rata-rata metode yang diterapkan pada TPA dikecamatan Amuntai Utara.Hasil penelitian diketahui bahwa penerapan metode membaca Alquran pada TPA di Kecamatan Amuntai Utara sangat berpengaruh terhadap kemampuan membaca Alquran santri. Hal ini dapat dilihat dari ;Kurikulum yang telah diterapkan. pada masing-masing TPA telah memiliki kurikulum yang diterapkan sesuai dengan metode, Pendekatan pembelajaran Alquran di TPA yang menerapkan metode Iqra lebih berorientasi kepada pendekatan individual. Sedangkan TPA yang menerapkan metode tilawati mengkombinasi antara keduanya pendekatan individual dan klasikal, Langkah pembelajaran dari masing-masing metode memiliki langkah pembelajaran yang berbeda,

Efektivitas metode Iqra dibanding dengan metode Tilawati berdasarkan hasil perhitungan statistiknya tidak ada perbedaan yang signifikan,karena diketahui bahwa nilai $\mathrm{T}$ hitung 0,656 sedangkan nilai $\mathrm{T}$ tabel 0,449 sehingga dapat diketahui bahwa $\mathrm{T}$ hitung $=0,656>\mathrm{T}$ tabel 0,449 dari hasil tersebut dapat disimpulkan bahwa Ha ditolak dan Ho diterima yaitu tidak adanya perbedaan yang signifikan antara efektifitas metode Iqra dan metode Tilawati dengan kemampuan membaca Al-Qur'an.
\end{abstract}

Kata Kunci: Metode, Tilawati, Iqra'

Jurnal Ilmiah Al QALAM, Vol. 11, No. 24, Juli-Desember 2017 
Muhammad Hamdani: Penerapan Metode Membaca Alquranpada Tpa Di Kecamatan Amuntai Utara (Studi Pada Metode Iqra Dan Metode Tilawati)

\section{A. Pendahuluan}

Alquran merupakan pedoman hidup umat Islam baik didunia maupun di akherat. Apabila berpedoman dengan Alquran dalam setiap gerak dan langkah, maka hidup akan terarah pada kebaikan dan jauh dari kemungkaran karenat itu sudah menjadi kewajiban bagi umat Islam untuk mempelajari Alquran. Tidak hanya membaca akan tetapi juga dipahami maknanya serta berusaha mengamalkan Alquran dalam kehidupan sehari-hari.

Umat Islam mempunyai tanggung jawab untuk melestarikan eksistensi Alquran. Oleh karena itu, sebagai konsekuensi logisnya umat Islam harus mempelajari, meyakini dan mengamalkan ajaran-ajaran yang terkandung di dalam Alquran. Pada hakekatnya Alquran merupakan salah satu kelangkaan kitab yang telah memberikan pengaruh begitu luas dan mendalam terhadap jiwa manusia. Bagi kaum muslimin, Alquran yang diturunkan kepada Rasulullah SAW yang merupakan risalah Allah kepada semua manusia. ${ }^{1}$ bahkan mulianya bagi para pelestari Alquran, Allah telah memberikan predikat terbaik, baik baik orng yang belajar dan mengajarkannya melalui sabda Rasulullah SAW.

Pembelajaran Alquran yang optimal akan melahirkan generasi Qur'ani yang mampu memakmurkan bumi dengan Alquran dan menyelamatkan peradaban dunia di masa mendatang. ${ }^{2}$ Syarat mutlak untuk memunculkan generasi Qur'ani adalah adanya pemahaman terhadap Alquran yang diawali dengan mampu membaca Alquran dengan baik dan benar sesuai dengan kaidah yang telah ditentukan.

\footnotetext{
2007), h. 11.

2 Hayatun Fardah Rudi Arifin, Belajar Alquran Strategis Siapkan Generasi
}

${ }^{1}$ Mudzakkir AS, Studi Ilmu -ilmu Quran (Jakarta: PT. Pustaka Litera Antarnusa, Qur'ani, (http://www.depag.go.id., (11 september 2015).

Jurnal Ilmiah Al QALAM, Vol. 11, No. 24, Juli-Desember 2017 
Muhammad Hamdani: Penerapan Metode Membaca Alquranpada Tpa Di Kecamatan Amuntai Utara (Studi Pada Metode Iqra Dan Metode Tilawati)

Langkah awal untuk mencapai hal tersebut adalah umat Islam harus mampu membaca huruf-huruf Alquran. Kemampuan membaca Alquran tidak dapat dipisahkan dari kegiatan pembelajaran Alquran. Oleh karena itu, dalam Islam pembelajaran Alquran merupakan suatu kewajiban yang suci dan mulia. Secara spesifik, Rasulullah saw. menegaskan kewajiban mendidik Alquran dalam hadisnya:

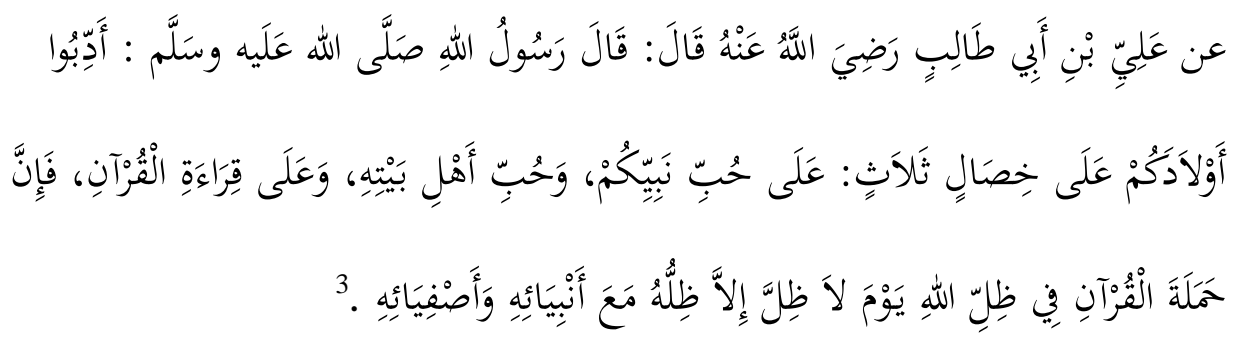

Hadis tersebut menjelaskan bahwa diantara pendidikan dasar yang harus diberikan kepada anak adalah membaca Alquran. ${ }^{4}$

Di dalam hadis yang lain Rasulullah saw. juga bersabda:

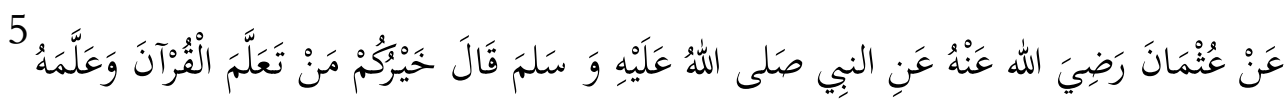

Realitanya banyak orang Islam yang hanya sekedar dapat membaca saja tanpa memperhatikan hukum bacaan dalam membaca Alquran, dimana keadaan ini tidak hanya terjadi dikalangan umat Islam yang awam saja, selain itu para pelajar, kaum intelektual, bahkan tokoh agamapun banyak diantara mereka yang belum dapat membaca Alquran dengan baik dan benar. Hal ini cukup memprihatinkan, karena mereka merupakan generasi penerus agama, bangsa, dan negara yang nantinya akan melanjutkan risalah

${ }^{3}$ As-Suyuthi, Jam 'ul Jawami' aw al-Jami'ul Kabir, (tp.), bab huruf hamzah, juz 1, hadits ke-924, h. 1251.

${ }^{4}$ Ahmad Syarifuddin, Mendidik Anak Membaca, Menulis, dan Mencintai Alquran, (Jakarta: Gema Insani Press, 2004), h. 28.

${ }^{5}$ Imam Abu Abdillahi Muhammad Ibnu Ismail, Kitab Shahih Bukhori, (Beirut, Lebanon: Darul Kutub Al Ilmiyah, 1992), Juz. 4. h. 1919.

Jurnal Ilmiah Al QALAM, Vol. 11, No. 24, Juli-Desember 2017 
Muhammad Hamdani: Penerapan Metode Membaca Alquranpada Tpa Di Kecamatan Amuntai Utara (Studi Pada Metode Iqra Dan Metode Tilawati)

ajaran-ajaran Islam yang dibawa oleh Nabi Muhammad SAW. Imam alGhozali berpendapat, bahwa :

"Alquran adalah kitab yang paling banyak dan paling kerap dibaca dan didengar orang seluruh dunia. Setidak-tidaknya lima kali dalam sehari semalam umat Islam baik sebagai pribadi maupun sebagai jamaah, selalu membaca ayat-ayat Alquran dalam shalat mereka. Kadar pembacaan Alquran dikalangan Muslimin beraneka ragam. Ada yang dapat membacanya dengan fasih sempurna, tetapi adapula yang masih sederhana, bahkan ada yang terbelakang sekali." ${ }^{6}$

Mengingat pentingnya pembelajaran Alquran, Rasulullah SAW. menganjurkan pembelajaran membaca Alquran dimulai sejak masa kanakkanak karena pada masa itu terkandung potensi belajar yang sangat kuat dan besar. Anak akan sangat peka menangkap sesuatu yang diperintahkan dan diajarkan sehingga mudah menerima pelajaran-pelajaran yang diberikan. Namun masalahnya, Alquran disampaikan dalam bahasa Arab dan tidak semua umat muslim di Indonesia menguasai bahasa tersebut. Belajar membaca Alquran artinya belajar mengucapkan lambang-lambang bunyi (huruf) tertulis. Walaupun kegiatan ini cukup sederhana, tetapi bagi siswa pemula merupakan kegiatan yang cukup kompleks, karena harus melibatkan berbagai hal, yaitu penglihatan, pendengaran, pengucapan disamping akal pikiran. Kedua hal terakhir ini bekerja secara mekanik dan simultan untuk melahirkan perilaku membaca. Ditambah lagi materi yang dibaca adalah rangkaian kata-kata Arab yang banyak berbeda sistem bunyi dan

${ }^{6}$ Syaifullah Mahyudi, Permata Alquran, (Jakarta: CV. Rajawali, 1985), Cet. 1, h. 5.

Jurnal Ilmiah Al QALAM, Vol. 11, No. 24, Juli-Desember 2017 
Muhammad Hamdani: Penerapan Metode Membaca Alquranpada Tpa Di Kecamatan Amuntai Utara (Studi Pada Metode Iqra Dan Metode Tilawati)

penulisannya dengan yang mereka kenal dalam bahasa ibu dan bahasa Indonesia. $^{7}$

Usaha memberantas buta huruf Alquran, sudah mulai disadari oleh pemerintah dan sebagian masyarakat kita. Berbagai upaya yang dilakukan oleh Pemerintah daerah, para tokoh masyarakat dan pemuka agama.

Berdasarkan Surat Keputusan Bersama Menteri Dalam Negeri dan Menteri Agama No. 182/44 tahun 1982, dicantumkan tentang usaha-usaha peningkatan, penghayatan dan pengamalan Alquran dalam kehidupan sehari-hari yang berisikan sebagai berikut:

Meningkatkan kemampuan baca tulis Alquran bagi umat Islam dalam rangka pelaksanaan usaha Lembaga Pengembangan Tilawatil Quran (LPTQ). Meningkatkan penghayatan dan pengamalan akan Alquran dalam kehidupan sehari-hari sebagaimana dimaksudkan dalam Keputusan Bersama Menteri Dalam Negri dan Menteri Agama No. 19 tahun 1977/151 tahun 1977 tentang pembentukan Lembaga Pengembangan Tilawatil Qur'an (LPTQ). ${ }^{8}$

Lembaga BKPRMI sebagai pusat pengembangan pembelajaran Alquran yang menaungi Taman Kanak-kanak Alquran (TKQ) Taman Pendidikan Alquran (TPA/TPQ) Lembaga Pendidikan Alquran (LPQ) di Indonesia.

Taman Pendidikan Alquran atau Lembaga Pendidikan Alquran merupakan lembaga pendidikan luar sekolah (non formal) jenis keagamaan. Muatan pengajaran TKQ/TPA lebih menekankan aspek keagamaan dengan mengacu pada sumber utamanya, yaitu Alquran dan Hadits.

\footnotetext{
${ }^{7}$ Depag RI, Metode-metode Membaca Alquran di Sekolah Umum, (Jakarta: Dirjen Pembinaan Kelembagaan Agama Islam, 1997), h. 24.

${ }^{8}$ Yariah, "Pendidikan Al Qur'an di Lingkungan Majelis Ta'lim Desa Kambitin Raya Tanjung Tabalong”. Skripsi, (Banjarmasin: Perpustakaan STAI Al Jami, 2003), h. 2.
}

Jurnal Ilmiah Al QALAM, Vol. 11, No. 24, Juli-Desember 2017 
Muhammad Hamdani: Penerapan Metode Membaca Alquranpada Tpa Di Kecamatan Amuntai Utara (Studi Pada Metode Iqra Dan Metode Tilawati)

Pertumbuhan dan perkembangan TKQ/TPA cukup pesat dan semarak di seluruh tanah air. "Berdasarkan hasil penelitian dari badan LITBANG Departemen Agama RI tahun 1990, bahwa perkembangan TPA dan LPQ dari tahun 1995 ke tahun 2000 mencapai $30 \%$, yaitu pada tahun 1998 jumlah TPA yang terdaftar di Departemen Agama sebanyak 40.000 buah, pada tahun 2000 jumlah TPA diseluruh Indonesia meningkat menjadi 41.600 buah. $^{\prime 9}$ Hal ini sebagai indikasi adanya sambutan dan dukungan yang cukup baik dari masyarakat dan adanya kepedulian umat dalam upaya pewarisan dan penanaman nilai-nilai keimanan dan ketaqwaan. Bagi generasi mendatang keberadaan dan pertumbuhan unit-unit pendidikan non formal jenis keagamaan itu pun cukup strategis untuk menunjang dan membantu anak dalam meraih prestasi belajar di pendidikan formal. TPA mempunyai pengaruh yang besar terhadap pendidikan keagamaan anak dalam upaya memberikan pembekalan dasar dan motivasi belajar anak untuk melanjutkan pendidikannya ke jenjang yang lebih tinggi guna meraih prestasi dan mewujudkan cita-cita, juga harapan orang tua, agama dan bangsa. Demikian pula TPA yang kini mulai marak tersebar, berbagai metode pun digunakan dalam mencetak generasi Muslim Qur'ani yang berilmu dan berakhlaqul karimah dengan pemahaman dan pengamalan Alquran sebagai pedoman hidup. Untuk merangsang minat belajar sekaligus mempermudah belajar membaca Alquran khususnya bagi anak-anak, diperlukan metode yang tepat, efektif dan efisien. Penggunaan metode yang tepat dan efektif dalam proses belajar mengajar di lembaga-lembaga pendidikan, baik formal maupun non formal merupakan salah satu faktor pendukung tercapainya tujuan KBM (Kegiatan Belajar Mengajar) yang

\footnotetext{
${ }^{9}$ Hasan Muarif dan Ambari, Ensiklopedi Islam, (Jakarta: PT. Ichthiar Baru, 1996)
}

Jurnal Ilmiah Al QALAM, Vol. 11, No. 24, Juli-Desember 2017 
Muhammad Hamdani: Penerapan Metode Membaca Alquranpada Tpa Di Kecamatan Amuntai Utara (Studi Pada Metode Iqra Dan Metode Tilawati)

optimal, di samping guru yang profesional dan adanya sarana dan prasarana yang menunjang proses KBM tersebut.

Kemampuan membaca Alquran adalah kemampuan hasil belajar Alquran yang diperoleh siswa dengan diperlihatkannya setelah mereka menempuh pembelajaran. Kemampuan membaca Alquran dipengaruhi oleh banyak faktor salah satunya adalah metode yang digunakan guru dalam pembelajaran. Guru harus mampu memilih metode yang sesuai dengan materi yang akan diajarkan. Dalam setiap pertemuan guru dapat menggunakan beberapa macam metode. Keserasian penggunaan metode itu sangat bergantung pada pengetahuan guru tentang metode yang diuji oleh pengalaman guru itu sendiri. Dalam pelaksanaanya kadangkala metode yang digunakan tidak sesuai dengan hasil yang diinginkan. Bila kenyataan seperti ini dialami oleh guru, maka guru harus sabar dan berusaha memecahkan kesulitannya yakni dengan berusaha memperkaya dirinya dengan pengetahuan metode sehingga dalam mengajar guru dapat meningkatkan lagi pengajarannya melalui berbagai macam metode yang ia kuasai dan mengganti metode yang kurang sesuai dengan metode lain yang menurut anggapannya lebih sesuai. Penggunaan metode yang tepat oleh seorang guru dalam mengajarkan membaca Alquran maka akan memberikan pengaruh yang sangat besar pula terhadap efektifitas pembelajaran dan implikasinya terhadap kemampuan siswa dalam membaca Alquran. Tanpa metode suatu pesan pembelajaran tidak akan berproses secara efektif ke arah yang ingin dicapai. Pada dekade belakangan ini telah banyak metode pengajaran baca tulis Alquran dikembangkan, begitu juga buku-buku panduannya telah banyak disusun dan dicetak. Metode apapun yang berkembang, masingmasing mempunyai kelebihan dan kekurangan. Efektifitas, efisiensi, cepat mudahnya sebuah metode pengajaran berbeda-beda di tiap daerah. Banyak

Jurnal Ilmiah Al QALAM, Vol. 11, No. 24, Juli-Desember 2017 
Muhammad Hamdani: Penerapan Metode Membaca Alquranpada Tpa Di Kecamatan Amuntai Utara (Studi Pada Metode Iqra Dan Metode Tilawati)

sekali jenis teknik, metode, metodologi dalam pembelajaran Alquran mulai dari cara klasik sampai modern. Pada saat ini berkembang metode-metode praktis dan cepat belajar Alquran dengan berbagai macam kelebihan yang ditampilkan.

Metode yang sering digunakan di TPA, adalah: Metode Qiraati, Metode Tilawati, Metode Iqra, Metode Aba Ta Tsa, Metode Ummi, Metode Al-Tibyan, dan lain sebagainya. Berbagai metode tersebut yang digunakan dilembaga-lembaga pengajaran Alquran seperti TPA tentu saja memiliki kelebihan dan kekurangan. Dari sini BKPRMI kabupaten Hulu Sungai Utara selaku lembaga yang menaungi TPA yang ada di kecamatan Amuntai Utara terus memberikan apresiasi kepada TPA untuk menentukan metode pembelajaran Alquran yang cocok dan sesuai untuk diterapkan pada masing-masing lembaga guna mempermudah para peserta didiknya dalam membaca Alquran dengan baik dan benar.

Metode yang diterapkan di TPA yang ada di kecamatan Amuntai Utara sebagian besar adalah metode Iqra' dan beberapa TPA yang menggunakan metode Tilawati. ${ }^{10}$ Sebagian guru menganggap bahwa pada masing-masing metode merasa cocok diaplikasikan dalam mengajarkan kepada para santri karena dalam metode ini terdapat beberapa prinsip yang dapat diaplikasikan dalam praktek pembelajaran membaca Alquran sehingga memudahkan para siswa untuk mampu membacanya dengan baik dan benar sesuai kaidah ilmu tajwid. Namun pada pengamatan peneliti sebelumnya, dalam realita sehari-hari tampak jelas bahwa santri memiliki perbedaan dalam hal motivasi dan kemampuan dalam membaca Alquran yang terkadang sangat mencolok antara seorang santri dengan santri lainnya sehingga menyebabkan adanya implikasi serius pada proses pembelajaran

${ }^{10}$ Observasi dan wawancara dengan Teddy Suryana, DPD BKPRMI HSU 20 Februari 2016.

Jurnal Ilmiah Al QALAM, Vol. 11, No. 24, Juli-Desember 2017 
Muhammad Hamdani: Penerapan Metode Membaca Alquranpada Tpa Di Kecamatan Amuntai Utara (Studi Pada Metode Iqra Dan Metode Tilawati)

yang menghambat tercapainya tujuan pembelajaran dan perbedaan pada hasil kemampuan belajar yang dicapai oleh santri pada setiap lembaga TPA yang ada di kecamatan Amuntai Utara. Berlatar belakang hal di atas, peneliti berencana untuk melakukan penelitian tesis dengan judul PENERAPAN METODE MEMBACA ALQURAN PADA TPA DI KECAMATAN AMUNTAI UTARA ( studi pada metode Iqra dan Tilawati).

\section{B. Metode}

Penelitian ini adalah penelitian lapangan (field research) yaitu mengambil TPA yang menerapkan metode Iqra dan Tilawati di kecamatan Amuntai Utara sebagai tempat penelitian. sedangkan Metode dalam penelitian ini menggunakan pendekatan Mixed method yakni menghasilkan fakta yang lebih komprehensif dalam meneliti masalah penelitian, karena peneliti ini memiliki kebebasan untuk menggunakan semua alat pengumpul data sesuai dengan jenis data yang dibutuhkan. Sedangkan kuantitatif atau kualitatif hanya terbatas pada jenis alat pengumpul data tertentu saja.

Fokus penggabungan dua metode (kualitatif dan kuantitatif) lebih pada teknik pengumpulan data dan analisis data, sehingga peneliti dapat membandingkan seluruh data temuan dari kedua metode tersebut, yang selanjutnya diperoleh kesimpulan dan saran apakah kedua data saling memperkuat, memperlemah atau bertentangan. Untuk rumusan masalah 1 tentang "bagaimana penerapan metode membaca Alquran di TPA Kecamatan Amuntai Utara", peneliti lebih menekankan penggunaan teknik pengumpulan data secara kualitatif yaitu dengan melakukan wawancara terhadap beberapa orang guru, kepala TPA, dan pengurus BKPRMI yang terlibat dalam proses penerapan metode. Sedangkan untuk menjawab 
Muhammad Hamdani: Penerapan Metode Membaca Alquranpada Tpa Di Kecamatan Amuntai Utara (Studi Pada Metode Iqra Dan Metode Tilawati)

rumusan masalah ke 2 tentang"Seberapa besar efektifitas metode membaca Alquran pada TKQ/TPA/TPQ di kecamatan Amuntai Utara", peneliti lebih menekankan penggunaan teknik pengumpulan data secara kuantitatif yaitu dengan melakukan tes kemampuan membaca Alquran, antara santri yang menerapkan mteode Iqra dan metode Tilawati.

Sumber data berupa data primer dan data sekunder, Data primer merupakan data yang diperoleh langsung dengan melakukan wawancara,melakukan tes, observasi maupun dokumentasi yang peneliti lakukan selama dilapangan. Adapun data sekunder yaitu data yang diperoleh lewat pihak lain, dan tidak langsung didapatkan oleh peneliti dari subyek penelitiannya. Data sekunder yaitu data yang mendukung atau memberi informasi yang bermanfaat yang berkaitan dengan penelitian, baik data internal maupun data eksternal. biasanya berwujud dokumentasi atau data laporan yang sudah tersedia. Data sekunder ini biasanya diperoleh dari otoritas atau pihak yang mempunyai kewenangan. Penggunaan data ini mempunyai tingkat efisiensi yang lebih tinggi, meskipun kadang-kadang kurang akurat. Untuk mendapatkan data-data tersebut adalah melalui sumber data, yakni :Responden yaitu santri yang dijadikan sampel dalam penelitian ini. Dan Informan yaitu Kepala TPA, Tata Usaha, dan OrangOrang yang di anggap perlu.

Tehnik analisis data kuantitatif menggunakan analisis data komparatif (T-test) dimana tehnik ini digunakan untuk menguji hipotesis mengenai ada tidaknya perbedaan antara variabel yang diteliti, jika ada perbedaan, apakah perbedaan itu signifikan ataukah perbedaan tersebut hanya kebetulan saja. Dalam hal ini penulis menggunakan software SPSS 22. Dengan analisis Independent Sample T Test pada prinsipnya tujuan uji dua sampel adalah ingin mengetahui apakah ada perbedaan rata-rata (mean)

Jurnal Ilmiah Al QALAM, Vol. 11, No. 24, Juli-Desember 2017 
Muhammad Hamdani: Penerapan Metode Membaca Alquranpada Tpa Di Kecamatan Amuntai Utara (Studi Pada Metode Iqra Dan Metode Tilawati)

antara dua populasi, dengan melihat rata-rata dari dua sampelnya.Dasar pengambilan keputusan ( uji varians menggunakan uji satu sisi):

1. Jika probabilitas $<0,05$ maka Ho diterima

2. Jika probabilitsa $>0,05$ maka Ho ditolak ${ }^{11}$

\section{Hasil Penelitian}

Dari penelitian yang telah dilaksanakan oleh peneliti diketahui bahwa Struktur pembelajaran ( Kurikulum) Alquran pada TPA di Kecamatan Amuntai Utara bisa dikatakan cukup terlaksana dengan baik, hal ini disebabkan karena tidak adanya hubungan antara pembina TPA dengan pelaksana TPA. Satu sisi Pembina TPA yakni BKPRMI belum memiliki kurikulum sementara TPA pelaksana sudah memiliki kurikulum yang dibuat sendiri (internal) dan diterapkan sendiri dan kurikulum yang diterapkan masing-masing berbeda. Hal ini bertolak belakang dengan teori implementasi kurikulum Menurut Martinus Yamin dimana guru menerapkan kurikulum yang telah dirancang oleh pemerintah dan instansi, dan mereka harus mampu mengajarkannya walaupun kurikulum baru berbeda dengan kurikulum sebelumnya, hal ini terjadi karena pengaruh penilaian kemajuan zaman dan untuk kecerdasan peserta didik sendiri dalam pengembangan pembelajaran. ${ }^{12}$ seharusnya BKPRMI sebagai Pembina dari TPA membuatkan kurikulum pembelajaran Al Quran sehingga bisa diselaraskan kepada seluruh TPA yang ada di kabupaten atau kecamatan.

Pendekatan dapat diartikan sebagai titik tolak atau sudut pandang kita terhadap proses pembelajaran. Istilah pendekatan merujuk kepada

\footnotetext{
${ }^{11}$ Singgih Santoso, Menguasai SPSS 21 di era Informasi. (Jakarta, PT. Elex Media Komputindo. 2013). .h. 250-256

${ }^{12}$ Martinis Yamin, Profesionalisasi dan Implementasi KBK.(Jakarta: Gaung Persada Press. 2006).h. 49
}

Jurnal Ilmiah Al QALAM, Vol. 11, No. 24, Juli-Desember 2017 
Muhammad Hamdani: Penerapan Metode Membaca Alquranpada Tpa Di Kecamatan Amuntai Utara (Studi Pada Metode Iqra Dan Metode Tilawati)

pandangan tentang terjadinya suatu proses yang sifatnya masih sangat umum.

Bersadarkan penyajian data terdahulu yang diperoleh di lapangan, tentang pendekatan yang dilakukan guru dalam menerapkan metode membaca Alquran ada dua pendekatan yaitu pendekatan klasikal dan individual. Dimana Pendekatan klasikal adalah proses belajar mengajar yang dilakukan dengan cara bersama-sama atau berkelompok dengan menggunakan peraga. Sedangkan Pendekatan individual dengan teknik baca simak adalah proses belajar mengajar yang dilakukan dengan cara membaca bergiliran yang satu membaca dan yang satu menyimak. Berdasarkan penyajian data terdahulu, maka dapat dikatahui bahwa ada dua pendekatan yang diterapkan dalam pembelajaran Al Quran di TPA Kecataman Amuntai Utara, yaitu pendekatan individual dan pendekatan klasikal. Sedangkan pendekatan individual lebih ditekankan pada penerapan metode Iqra sedangkan metode tilawati mencampur antara pendekatan individual dan klasikal.

Langkah-langkah pembelajaran Alquran diketahui bahwa adanya perbedaan langkah-langkah pembelajaran antara TPA yang menggunakan metode Iqra dan metode tilawati. Dalam metode Iqra diketahui bahwa metode lebih diperankan oleh guru sedangkan murid hanya menunggu perintah guru dan hanya menggunakan buku jilid pedoman Iqra saja, sedangkan metode tilawati diketahui bahwa murid dibagi beberapa kelompok dan di ajarkan teknik guru membacakan murid mendengarkan kemudian guru membaca kemudian murid menirukan bacaan guru kemudian membaca bersama-sama dengan peraga tilawati.

Langkah-langkah pembelajaran dalam pelaksannan dan pendidikan terhadap peserta didik tentunya seorang guru dapat mengembangkan sesuai

Jurnal Ilmiah Al QALAM, Vol. 11, No. 24, Juli-Desember 2017 
Muhammad Hamdani: Penerapan Metode Membaca Alquranpada Tpa Di Kecamatan Amuntai Utara (Studi Pada Metode Iqra Dan Metode Tilawati)

dengan situasi dan kondisi saat mengajar agar tercipta tujuan pendidikan secara optimal. Hal ini sesuai dengan teori langkah-langkah belajar Al Quran yaitu Guru menyiapkan materi yang akan diajarkan

a. Guru membaca atau memberikan contoh atas materi yang akan diajarkan

b. Guru menyuruh seorang murid untuk lebih mengulangi materi yang telah ia contohkan

c. Guru menyuruh murid-murid untuk membaca materi yang telah dicontohkan secara serempak

d. Guru harus cekatan dalam memperbaiki kesalahan bacaan muridmurid.

Secara penyampaian materi metode Iqra lebih pada direct method yakni murid langsung membaca sehingga yang menjadi fokus pembelajaran adalah murid, sedangkan pada metode Tilawati antara guru dan murid lebih seimbang. Sama-sama aktif, langkah teknik ini bertujuan agar pembelajarannya menjadi lebih efektif dan efisien, kemudian kalau dibaca bersama-sama itu yang belum bisa jadi niru-niru membaca, jadinya kalau melihat temannya membaca maka santri yang belum bisa akan termotivasi ingin ikut membaca juga sehingga proses pembelajarannya menjadi lebih kondusif.

Bersadarkan penyajian data terdahulu yang diperoleh melalui wawancara dapat diketahui bahwa latar belakang pendidikan guru pada masing-masing metode memiliki latar belakang pendidikan yang berbeda, meskipun berlatar belakang keagamaan secara umum namun guru pada metode tilawati memiliki pengalaman mengahafal Alquran sebelumnya, sehingga secara intraksi dengan Alquran guru pada metode tilawati lebih mahir, ditambah dengan pengalaman mengajar yang berbdeda pula, semakin

Jurnal Ilmiah Al QALAM, Vol. 11, No. 24, Juli-Desember 2017 
Muhammad Hamdani: Penerapan Metode Membaca Alquranpada Tpa Di Kecamatan Amuntai Utara (Studi Pada Metode Iqra Dan Metode Tilawati)

lama mengajar, membuat kualitas mengajar lebih baik, hal ini dipengaruhi oleh faktor pengalaman mengajar yang cukup lama, selain itu pula metode tilawati mengajar didukung oleh alat peraga. Dan setiap guru tilawati telah mengikuti standarisasi pengajr tilawati, sedangkan guru Iqra meskipun berpengalaman akan tetapi tidak ada penstandaran terhadap metode tersebut.

Output pertama yaitu gruop statistic, dapat diinterprtasikan bahwa jumlah data/sampel(N) sebanyak 24 untuk metode Iqra dan 18 untuk metode Tilawati, rata-rata kemampuan membaca Al Quran untuk yang menggunakan metode Iqra 68,17 dan yang menggunakan metode tilawati 67,78 nilai standart deviasi metode Iqra dan metode tilawati 2,777 , dan standart error of mean untuk metode Iqra 0,567 dan metode Tilawati 0,655 standart error of mean menggambarkan sebaran rata-rata sampel terhadap rata-rata dari rata-rata keseluruhan kemungkinan sampel.

Output kedua yaitu independent Sampel T, dapat digunakan untuk menguji apakah kedua metode memiliki rata-rata yang sama dan juga dapat digunakan untuk menguji apakah kedua metode memiliki varian yang sama hipotesisnya:

Ha : Kedua metode memiliki varian yang sama

Ho : Kedua metode tidak memiliki varian yang sama

Hasil perhitungan SPSS diatas diketahui nilai sig $(0,978)>0,05$ maka Ho diterima, artinya kedua metode memiliki varian yang sama. Selanjutnya terlihat bahwa T hitung untuk metode belajar Al quran dengan equalvariance assumed adalah 0,001 dengan probabilitas 0,978 dengan hipotesis :

$\mathrm{Ha} \quad$ : ( Rata-rata kemampuan membaca Al Quran santri yang menggunakan metode Iqra dan metode Tilawati sama)

Ho : ( Rata-rata kemampuan membaca Al Quran santri yang

Jurnal Ilmiah Al QALAM, Vol. 11, No. 24, Juli-Desember 2017 
Muhammad Hamdani: Penerapan Metode Membaca Alquranpada Tpa Di Kecamatan Amuntai Utara (Studi Pada Metode Iqra Dan Metode Tilawati)

menggunakan metode Iqra dan metode Tilawati tidak sama)

Karena probabilitas uji 2 sisi $(0,978 / 2=0,489)>0,025$, maka Ho diterima. Bahwa rata-rata kemampuan membaca Al Quran santri yang menggunakan metode Iqra dan metode Tilawati tidak sama.

\section{Hasil Uji Hipotesis}

Hipotesis dalam penelitian ini, yang diajukan adalah hipotesis alternative (Ha) dan Hipotesis nol (Ho) dengan rumusan sebagai berikut:

$\mathrm{Ha}$ : Adanya perbedaan yang signifikan antara efektifitas metode Iqra dan metode Tilawati dengan kemampuan membaca Al-Qur'an

Ho : Tidak Adanya perbedaan yang signifikan antara efektifitas metode Iqra dan metode Tilawati dengan kemampuan membaca Al-Qur'an

Membuktikan hipotesis ini, dilakukan dengan rumus uji $\mathrm{T}$ dengan kriteria :Hipotesis alternative ( $\mathrm{Ha}$ ) diterima jika $\mathrm{T}$ hitung yang dihasilkan oleh perhitungan lebih kecil dari T Tabel, berdasarkan derajat kebebasan yang digunakan dan hipotesis nol (Ho) diterima jika keadaan sebaliknya yaitu apabila T Hitung lebih besar dari T Tabel.

Berdasarkan hasil hitung menggunakan SPSS diketahui bahwa nilai $\mathrm{T}$ hitung 0,656 sedangkan nilai $\mathrm{T}$ tabel 0,449 sehingga dapat diketahui bahwa $\mathrm{T}$ hitung $=0,656>\mathrm{T}$ tabel 0,449 dari hasil tersebut dapat disimpulkan bahwa Ho diterima yaitu tidak adanya perbedaan yang signifikan antara efektifitas metode Iqra dan metode Tilawati dengan kemampuan membaca Al-Qur'an. Hal ini berdasarkan karena keterbatasan penelitian yang penulis lakukan, yaitu penilaian yang diambil dari masingmasing guru pada setiap metode, secara pelaksanaan dan penerapan kedua

Jurnal Ilmiah Al QALAM, Vol. 11, No. 24, Juli-Desember 2017 
Muhammad Hamdani: Penerapan Metode Membaca Alquranpada Tpa Di Kecamatan Amuntai Utara (Studi Pada Metode Iqra Dan Metode Tilawati)

metode memiliki standart perbedaan masing-masing hal ini dipengaruhi oleh faktor karakteristik guru, dimana kedua metode memiliki latar belakang pendidikan guru dan pengalaman mengajar yang berbeda,serta pengaruh alat peraga yang digunakan dan standart kompetensi yang berbeda pula, sehingga hal tersebut juga mempengaruhi efektivitas kedua metode dalam kemampuan membaca Alquran.

\section{E. Simpulan}

Berdasarkan hasil penelitian yang telah dilakukan berkaitan dengan judul penelitian "Penerepan metode membaca Alquran pada TPA di Kecamatan Amuntai Utara ". Berikut ini kesimpulan hasil penelitian.

1. Penerapan metode membaca Alquran pada TPA di Kecamatan Amuntai Utara sangat berpengaruh terhadap kemampuan membaca Alquran santri. Hal ini dapat dilihat dari:

a. Kurikulum yang telah diterapkan. pada masing-masing TPA telah memiliki kurikulum yang diterapkan sesuai dengan metode, akan tetapi terlihattidak adanya hubungan antara pembina TPA dengan pelaksana TPA. Pembina TPA yakni BKPRMI belum memiliki kurikulum sementara TPA pelaksana sudah memiliki kurikulum yang dibuat sendiri (internal) dan diterapkan sendiri dan kurikulum yang diterapkan masing-masing berbeda.

b. Pendekatan pembelajaran Alquran di TPA yang menerapkan metode Iqra lebih berorientasi kepada pendekatan individual. Sedangkan TPA yang menerapkan metode tilawati mengkombinasi antara keduanya pendekatan individual dan klasikal. Sedangkan dari pendekatan psikologi metode Iqra lebih pada pembelajaran induktif dan metode Tilawati berpusat pada guru dan murid ( student and teacher approaches) sehingga pendekatan yang 
Muhammad Hamdani: Penerapan Metode Membaca Alquranpada Tpa Di Kecamatan Amuntai Utara (Studi Pada Metode Iqra Dan Metode Tilawati)

berpusat pada guru dan murid menurunkan strategi pembelajaran langsung (direct instruction).

c. Langkah pembelajaran dari masing-masing metode memiliki langkah pembelajaran yang berbeda, namun secara keseluruhan langkah pembelajaran sudah berjalan dengan sangat baik, setiap metode bertujuan agar pembelajarannya menjadi lebih efektif dan efisien,

d. Karakteristik ustadz dan ustadzahnya yang terlihat bahwa guru yang menerapkan metode Iqra meskipun mengajar Alquran cukup lama, akan tetapi latar belakang pendidikan yang tidak berhubungan dengan Alquran, bukan seorang penghafal Alquran, belum pernah mengikuti standarisasi metode Iqra, sedangkan metode Tilawati guru-gurunya sudah berstandarisasi sebagai pengajar Tilawati, berlatar belakang pendidikan dibidang keilmuan Alquran dan sering mengikuti pelatihan-pelatihan metode membaca Alquran.

2. Efektivitas metode Iqra dibanding dengan metode Tilawati berdasarkan hasil perhitungan statistiknya tidak ada perbedaan yang signifikan,karena diketahui bahwa nilai $\mathrm{T}$ hitung 0,656 sedangkan nilai $\mathrm{T}$ tabel 0,449 sehingga dapat diketahui bahwa $\mathrm{T}$ hitung $=0,656>$ T tabel 0,449 dari hasil tersebut dapat disimpulkan bahwa $H a$ ditolak dan $\mathrm{Ho}$ diterima yaitu tidak adanya perbedaan yang signifikan antara efektifitas metode Iqra dan metode Tilawati dengan kemampuan membaca Al-Qur'an.

Jurnal Ilmiah Al QALAM, Vol. 11, No. 24, Juli-Desember 2017 
Muhammad Hamdani: Penerapan Metode Membaca Alquranpada Tpa Di Kecamatan Amuntai Utara (Studi Pada Metode Iqra Dan Metode Tilawati)

\section{Daftar Pustaka}

Arifin, Hayatun Fardah Rudi. Belajar Al-Qur'an Strategis Siapkan Generasi Qur'ani,http://www.depag.go.id.diakses 11 september 2015

As-Suyuthi, Jam'ul Jawami' aw al-Jami'ul Kabir, CD: al-Maktabah alSyâmilah, t.th

Depag RI, Metode-metode Membaca Alquran di Sekolah Umum, Jakarta: Dirjen Pembinaan Kelembagaan Agama Islam, 1997.

Ismail, Imam Abu Abdillahi Muhammad Ibnu. ShahihBukhori, Beirut, Lebanon: Darul Kutub Al Ilmiyah1992.

Mudzakir As. Studi Ilmu-ilmu Qur'an, Jakarta: Penerbit Litera AntarNusa. 2007.

Santoso, Singgih, Menguasai SPSS 21 di era Informasi. Jakarta, PT. Elex Media Komputindo. 2013.

Syaifullah Mahyudi, Permata Alquran, Jakarta: CV. Rajawali, 1985, Cet. 1.

Syarifuddin, Ahmad. Mendidik Anak Membaca, Menulis, dan Mencintai AlQur'an. Jakarta: Gema Insani Press. 2004

Yamin, Martinis. Profesionalisasi dan Implementasi KBK. Jakarta: Gaung Persada Press. 2006.

Yariah, Pendidikan Al Qur'an di Lingkungan Majelis Ta'lim Desa Kambitin Raya Tanjung Tabalong. Skripsi.Banjarmasin: Perpustakaan STAI Al Jami, 2003

Jurnal Ilmiah Al QALAM, Vol. 11, No. 24, Juli-Desember 2017 